SHORT COMMUNICATION

\title{
Characterization of mesenchymal stem cells derived from adipose tissue of a cougar (Puma concolor)
}

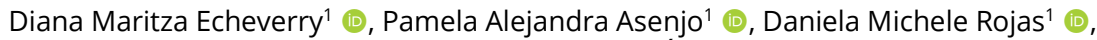

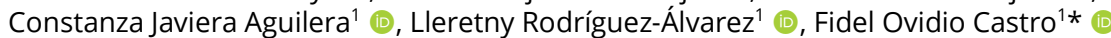

${ }^{1}$ Department of Animal Science, Faculty of Veterinary Sciences, Universidad de Concepción, Concepción, Chile

How to cite: Echeverry DM, Asenjo PA, Rojas DM, Aguilera CJ, Rodríguez-Álvarez L, Castro FO. Characterization of mesenchymal stem cells derived from adipose tissue of a cougar (Puma concolor). Anim Reprod. 2020;17(2):e20190109. https://doi.org/10.1590/1984-3143-AR2019-0109

\begin{abstract}
Adipose derived mesenchymal stem cells (AMSCs) have been isolated from domestic and wild cats. For wild cats, the isolation of AMSCs has been reported in the black-footed cats (Felis nigripes) and guigna (Leopardus guigna). Stromal vascular fraction (SVF) isolated from cougar adipose tissue have been used to restore elbow functionality in the cougar (Puma concolor) but multipotent characteristics of these cells have not been described. The present study describes for the first time the isolation and characterization of mesenchymal stem cells derived from adipose tissue of cougar. AMSCs and fibroblasts from six months female cougar were isolated and cultured in DMEM/F12, supplemented with FBS $10 \%+1 \%$ Antibiotic/Antifungal + 2.4 mM L-Glutamine + 2.4 mM pyruvate up to passage 5. Expression of pluripotent and surface marker genes was evaluated at mRNA level. Mesodermal differentiation (adipogenic, osteogenic and chondrogenic) was described. AMSCs expressed mRNA of pluripotent genes Oct4, Nanog, Sox2 and Klf4 and surface markers Cd44,Cd90, Cd105 and MHCII. Fibroblasts showed similar mRNA expression with the exception of Sox2. AMSCs obtained from cougar exhibit multipotency features similar to domestic cats MSC, nevertheless, other analyses are required. AMSCs from cougar could be a source of interest for treatment of individuals that remain in captivity or arrive to wildlife rehabilitation centers.
\end{abstract}

Keywords: cell therapy, feline, Puma concolor, stem cell, wild cat.

\section{Introduction}

The isolation of mesenchymal stem cells (MSCs) from several tissues represents an opportunity for their use in cell therapy in domestic and / or threatened animals. Although in domestic cats their isolation and characterization from different tissues has been widely described, for wild cats there are only few reports of isolation of this type of cells (Gómez et al., 2015; Echeverry et al., 2019). The collection of tissue samples from wild cats is difficult because mainly they are endangered species and specimens are rarely available to perform this procedure. Despite this, previous studies reported similar characteristics between AMSC of domestic and wild cats such as Felis nigripes and Leopardus guigna (Gómez et al., 2015; Echeverry et al., 2019). AMSCs from wild cats demonstrated multilineage differentiation capacity toward mesoderm cell lineages as adipogenic, osteogenic and chondrogenic, but also toward ectoderm cell lineage in case of Felis nigripes (Gómez et al., 2015; Echeverry et al., 2019). AMSCs from Leopardus guigna showed mRNA expression of Oct4, Nanog, CD44 and CD90 (Echeverry et al., 2019). These previous studies suggest that AMSCs from wild cats have important features of multipotent cells. 
Likewise, the use of MSCs for cell therapy in threatened and captive species has been scarce and poorly reported. The Puma concolor is one of the most common species in zoos and rehabilitation centers and displays pathologies similar to domestic cats, some of which could be potentially treated by means of cell therapy (Holsback et al., 2013; Miller et al., 2018). The objective of this study was to characterize a cellular population isolated from abdominal adipose tissue of a puma in order to determine its potential for cell therapy in this species.

\section{Materials and methods}

\section{Collection and isolation of AMSCs}

This study was approved by the Ethical Committee for Animal Experimentation of the Universidad de Concepción, permit number: CBE-03-2019. Peritoneal adipose tissue was isolated during the ovarian-hysterectomy procedure of a female cougar approximately 6 months old that was assigned to a rehabilitation center. The adipose tissue was homogenized and digested in type I collagenase at $0.01 \%$ at $37^{\circ} \mathrm{C}$ for $30 \mathrm{~min}$. It was filtered and centrifuged at $140 \times \mathrm{g}$ for 5 minutes to isolate stromal vascular fraction (SVF). The pellet was resuspended in 20\% SFB / DMEM + 1\% Antibiotic/Antifungal + $2.4 \mathrm{mM}$ L-Glutamine + 2.4 mM Pyruvate. The isolated cellular fraction was cultivated as primary cells. Cells were tested free of mycoplasmas contamination by multiplex PCR following the protocol previously reported (Table 1) (Uphoff and Drexler, 2002, 2004). Kinetics of cell growth was evaluated by quantitation of doubling population time after cell staining and counting using built-in software. No karyotype was performed. Cells were frozen after the first trypsinization (passage 1).

Table 1. Primer sequences used for Mycoplasma detection on fibroblasts and AMSC from cougar.

\begin{tabular}{|c|c|c|}
\hline \multicolumn{2}{|c|}{ Forward Primers } & Reference \\
\hline Мyсо-5-1 & CGCCTGAGTAGTACGTTCGC & \multirow{6}{*}{ Uphoff and Drexler $(2002,2004)}$. \\
\hline Myco-5-2 & CGCCTGAGTAGTACGTACGC & \\
\hline Myсо-5-2 & TGCCTGAGTAGTACATTCGC & \\
\hline Мyсо-5-2 & TGCCTGGGTAGTACATTCGC & \\
\hline Myco-5-5 & CGCCTGGGTAGTACATTCGC & \\
\hline Мyсо-5-6 & CGCCTGAGTAGTATGCTCGC & \\
\hline \multicolumn{2}{|c|}{ Reverse Primers } & \multirow{4}{*}{ Uphoff and Drexler $(2002,2004)$} \\
\hline Мyсо-3-1 & GCGGTGTGTACAAGACCCGA & \\
\hline Мyсо-3-2 & GCGGTGTGTACAAAACCCGA & \\
\hline Myсо-3-3 & GCGGTGTGTACAAACCCCGA & \\
\hline
\end{tabular}

\section{In vitro multilineage differentiation}

Adipogenic, osteogenic and chondrogenic differentiation assays were performed after thawing primary cells, in passage 2. For the adipogenic differentiation the cells were cultured in induction medium containing DMEM 10\% SFB supplemented with $1 \mu \mathrm{M}$ dexamethasone, $0.5 \mathrm{mM}$ 3- isobutyl-L-methylxanthine and $0.1 \%$ insulin-transferrin-selenium-X. At day 7 of differentiation the cells were fixed in 4\% paraformaldehyde and stained with Oil Red for $20 \mathrm{~min}$. For osteogenic differentiation the cells were cultured in induction medium consisting of DMEM with 10\% SFB, $1 \%$ antibiotic / antifungal, $0.1 \mu \mathrm{M}$ dexamethasone, $0.2 \mathrm{mM}$ ascorbic acid and $10 \mathrm{mM} \beta$-glycerol phosphate. On day 21 the samples were fixed in 4\% paraformaldehyde stained with $1 \%$ alizarin red to detect calcium deposits. Chondrogenic differentiation was performed as previously described with minor modifications (Castro et al., 2014). For chondrogenic induction cells were suspended in $500 \mu \mathrm{l}$ chondrogenic medium, centrifuged at $140 \times \mathrm{g}$ for $5 \mathrm{~min}$ in $15-\mathrm{ml}$ polypropylene conical tubes for culture in micro mass. Pelleted cells were incubated at $38.5^{\circ} \mathrm{C}$ under $5 \% \mathrm{CO}_{2}$ in chondrogenic medium (DMEM/F12 supplemented with $10 \% \mathrm{FBS}, 4.5 \mathrm{gr} / \mathrm{L}$ 
D-glucose, $10 \mu \mathrm{l} / \mathrm{mL}$ insulin- transferrin-selenium (ITS; Gibco), and $100 \mathrm{nM}$ dexamethasone, $1 \mu \mathrm{M}$ ascorbic acid 2-phosphate, and 2.5\% equine platelet rich plasma (ePRP)) for 30 days. Cells were fixed and stained with Alcian Blue. Cells of control groups were cultured in DMEM/F12 supplemented with 10\% FBS + 1\% Antibiotic/Antifungal + 2.4 mM L-Glutamine + 2.4 mM Pyruvate, without other supplements, for the same time periods as in experimental groups. All stained cells were visualized with phase-contrast optics on an inverted microscope (Olympus CKX-41). All reagents were from Sigma -Aldrich, St Louis, MO, USA.

\section{RT-PCR analyses}

The expression of Oct4, Nanog, KIf4, Sox2, Cd44, Cd90, Cd105 and MHCII mRNA were tested by RT-PCR. The set of primers used has been tested before for Felis catus and Leopardus guigna species in our laboratory (Echeverry et al., 2019 and unpublished results). Feline Sdha (succinate-dehydrogenase-complex-flavoprotein subunit A) housekeeping was used as internal standard (Table 2). Total RNA was isolated from cougar AMSCs and dermal fibroblasts at P2 to compare expression. RNA was extracted from each sample using an EZNA RNA extraction kit (Omega, Georgia, USA). The first-strand, cDNA, was synthesized from 500 ng of DNase-treated total RNA using 50 ng random hexamers (Invitrogen, Waltham, Massachusetts, USA) and $200 U$ of MMLV reverse transcriptase (New England Biolabs Ipswich, Massachusetts, USA) according to the manufacturer's instructions. RT-PCR amplification was performed in a $10 \mu \mathrm{l}$ reaction mixture in 40 cycles under the following conditions: $94^{\circ} \mathrm{C}$ for $30 \mathrm{~s}, 58^{\circ} \mathrm{C}$ for $30 \mathrm{~s}$, and $72{ }^{\circ} \mathrm{C}$ for $40 \mathrm{~s}$, with additional seven min incubation at $72{ }^{\circ} \mathrm{C}$ after cycle completion. Final PCR product was visualized in $1 \%$ agarose gel.

Table 2. Primer sequences used for the detection of gene expression in AMSC and fibroblasts from cougar.

\begin{tabular}{|c|c|c|c|c|c|}
\hline $\begin{array}{l}\text { Primer } \\
\text { sets }\end{array}$ & Species & Sequence & $\begin{array}{l}\text { Amplicon } \\
\text { size in bp }\end{array}$ & $\begin{array}{c}\text { Annealing } \\
\text { temperature } \\
\text { in }{ }^{\circ} \mathrm{C}\end{array}$ & $\begin{array}{l}\text { NCBI accesion } \\
\text { number }\end{array}$ \\
\hline \multirow{2}{*}{ SDHA } & \multirow{2}{*}{$\begin{array}{c}\text { Felis } \\
\text { silvestris }\end{array}$} & F: 5'- GGACCATGAATTTGACGCGG-3' & \multirow{2}{*}{103} & \multirow{2}{*}{59} & \multirow{2}{*}{ XM_011287219.1 } \\
\hline & & R: 5'- TCGGAGCCTTTCACAGTGTC -3' & & & \\
\hline \multirow{2}{*}{ OCT4 } & \multirow{2}{*}{$\begin{array}{c}\text { Felis } \\
\text { silvestris }\end{array}$} & F: 5'- TGCAGCTCAGTTTCAAGAACA -3' & \multirow{2}{*}{112} & \multirow{2}{*}{52} & \multirow{2}{*}{ NM_001173441.1 } \\
\hline & & R: 5'- ACAAGTGTCTCTGCTTTGCATA -3' & & & \\
\hline \multirow{2}{*}{ NANOG } & \multirow{2}{*}{$\begin{array}{c}\text { Felis } \\
\text { silvestris }\end{array}$} & F: 5'- ATGCACCCTTGCGAATGTCA -3' & \multirow{2}{*}{120} & \multirow{2}{*}{55} & \multirow{2}{*}{ NM_001173442.1 } \\
\hline & & R:5'- TTACTCTGGGGCTGGTGGAA -3' & & & \\
\hline \multirow{2}{*}{ sox2 } & \multirow{2}{*}{$\begin{array}{l}\text { Canis } \\
\text { lupus }\end{array}$} & F:5'-AACGGCAGCTACAGCATGAT-3' & \multirow{2}{*}{138} & \multirow{2}{*}{57} & \multirow{2}{*}{$\underline{X M ~} 005639752.3$} \\
\hline & & R: 5'-CGAGCTGGTCATGGAGTTGTA-3' & & & \\
\hline \multirow{2}{*}{ KLF4 } & \multirow{2}{*}{$\begin{array}{c}\text { Felis } \\
\text { silvestris }\end{array}$} & F: $5^{`}$-GTCCCATCAGGAGTCAGTGG-3’ & \multirow{2}{*}{207} & \multirow{2}{*}{59} & \multirow{2}{*}{ NM 001173444.1} \\
\hline & & R: 5'-GTCCAATTCAGGCCGAAGGA-3' & & & \\
\hline \multirow{2}{*}{ CD44 } & \multirow{2}{*}{$\begin{array}{c}\text { Felis } \\
\text { silvestris }\end{array}$} & F: 5' - TCGAGGCACCCCATTTCATAGACA -3' & \multirow{2}{*}{128} & \multirow{2}{*}{60} & \multirow{2}{*}{ XM_019812274.2 } \\
\hline & & R: 5'-ATCAGCTGGCTACTCTGTTGGACT-3' & & & \\
\hline \multirow{2}{*}{ CD90 } & \multirow{2}{*}{$\begin{array}{l}\text { Puma } \\
\text { concolor }\end{array}$} & F: 5' - AGCACGTGATCTTTGGCACTATGG -3' & \multirow{2}{*}{134} & \multirow{2}{*}{59} & \multirow{2}{*}{ XM_025929117.1 } \\
\hline & & R: 5-' ACATGTGTACATCCCCTCGTCCTT-3' & & & \\
\hline \multirow{2}{*}{ CD105 } & \multirow{2}{*}{$\begin{array}{c}\text { Puma } \\
\text { concolor }\end{array}$} & F: 5' - ATCACCTTTGGCGCCTTCCTTATC -3' & 14 & 59 & 38441 \\
\hline & & R: 5' -GTGGTTGGTGCTACTGCTTTCTGA-3' & 144 & 59 & XM_025913844.1 \\
\hline & Puma & F: 5'-TGAGCTGAAGTGGAGATGCTGACA-3' & & 60 & \\
\hline $\mathrm{MHCll}$ & concolor & R: 5'-ACTGAACCCAGGGCAAACCAAA-3' & 138 & 60 & XM_025926082.1 \\
\hline
\end{tabular}

\section{Immunocytochemistry}

Immunohistochemistry was performed to detect OCT4 and SOX2 proteins. Cells were fixed with 4\% paraformaldehyde for $5 \mathrm{~min}$ and incubation was carried out for $1 \mathrm{~h}$ with polyclonal primary antibodies, anti-OCT4 (1:200, Thermo Scientific, PA1-16943) and anti-SOX2 
(1:25, Thermo Scientific, PA5-17282) followed by a $1 \mathrm{~h}$ incubation with secondary anti-rabbit IgG-HRP conjugated (1:1000, Thermo Scientific, PA31463). Controls included: 1) no primary antibody, and incubation with the same secondary antibody and conditions as above and 2) specific primary antibodies (same conditions as above) and unspecific anti-mouse IgG (1:1000, Thermo Scientific PA 31430). The same primary antibodies had been tested previously in our laboratory (Cabezas et al., 2014). Nuclei and cytoplasm were counterstained with hematoxylin-eosin.

\section{Results}

AMSCs from cougar attached to the plastic surface of culture dishes and displayed fibroblastic morphology, with a spindle-like form, polygonal, and elongated shape. This morphology was also found in skin fibroblasts isolated from the same animal and remained cat fibroblasts and MSCs (Figure 1).

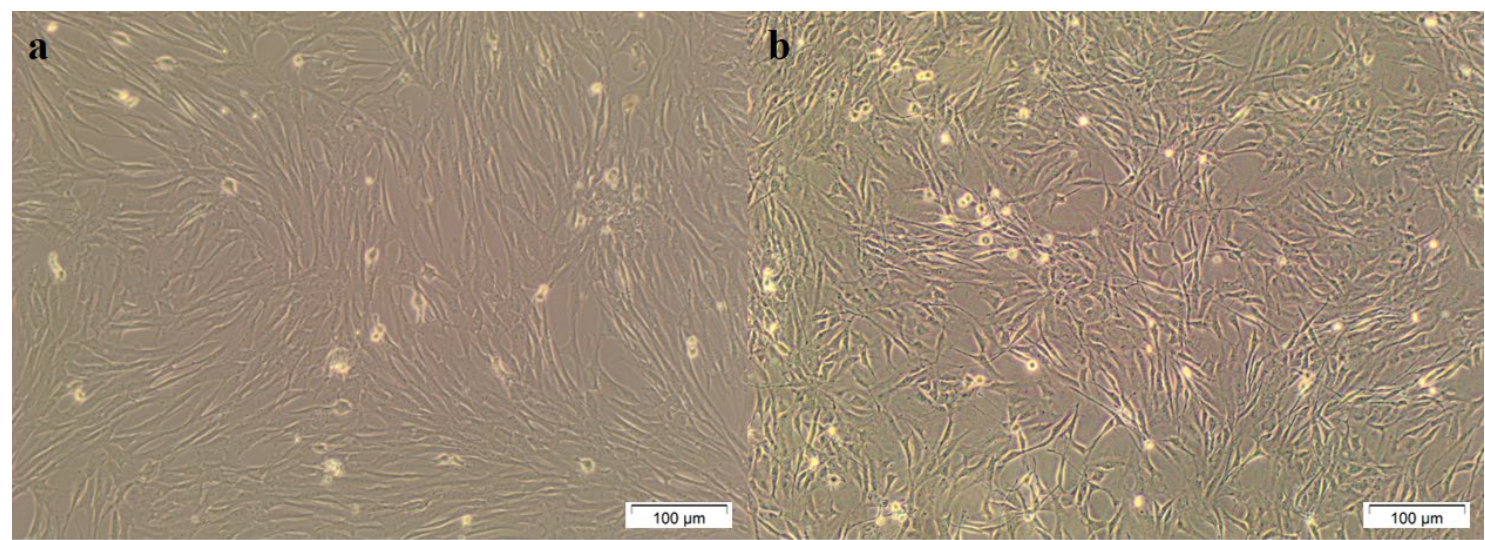

Figure 1. Cougar AMSC and fibroblasts cultured in vitro. (a) AMSC from cougar at P1; (b) Fibroblasts from cougar at P1.

AMSCs grew fast after initial plating. After P5 cells showed signs of senescence and started to detach from the culture dish. The cell doubling time for fibroblasts was longer than for AMSC (Table 3).

Table 3. Cell doubling time for cougar fibroblasts and AMSC in hours. The cell doubling time between P0 and P1 for fibroblasts could not be calculated since the culture was established from skin explants and was defined as PO.

\begin{tabular}{cccccc} 
Cell type/passage & P1 & P2 & P3 & P4 & P5 \\
\hline AMSC & 20.67 & 31.08 & 32.26 & 46.45 & 32 \\
\hline FIBROBLASTS & & 42.85 & 102.0 & 130.3 & 192 \\
\hline
\end{tabular}

Cougar AMSCs displayed differentiation capacity towards adipogenic, osteogenic and chondrogenic lineages. Presence of lipid vacuoles was evident at day 7 of culture in the differentiation medium and further confirmed after Oil Red stain. Alizarin Red stained calcium deposits at day 21, whereas control cells remained without morphological changes and negative to staining. Pellet formation was identified in chondrogenic differentiation and glycosaminoglycans were stained by Alcian blue (Figure 2). 

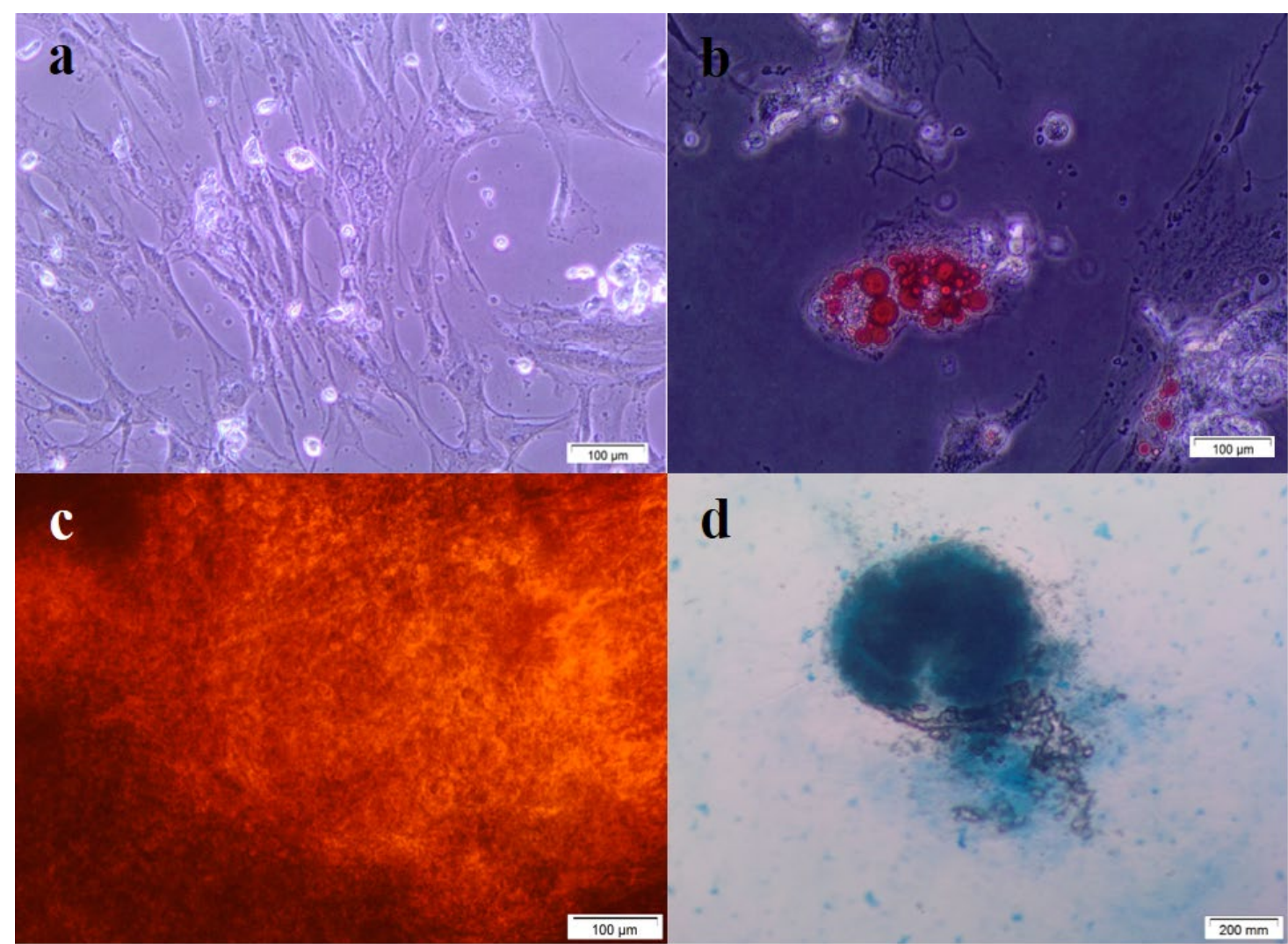

Figure 2. Multilineage differentiation of cougar AMSC. Cells showed differentiation capacity towards adipogenic, chondrogenic and osteogenic lineages. (a) Control without differentiation; (b) In adipogenic differentiation cells showed an increased granularity and larger intracellular oil droplets stained red by Oil Red; (c) Osteogenic induction was evidenced by calcium phosphate deposit stained red by Alizarin Red; (d) Aggregates with proteoglycan content after 28 days of chondrogenic induction culture showed intense Alcian Blue staining.

Pluripotent genes Oct4, Nanog, Sox2 and Klf4 and cell surface markers (Cd44, Cd90, Cd105 and $\mathrm{MHCII}$ ) were detected by RT-PCR in AMSC (Figure 3). Oct4, Nanog and KIf4 mRNA were detected also in fibroblast cells from cougar, whereas Sox 2 was not. All of the surface markers analyzed (Cd44, Cd90, Cd105 and MHCII) were detected also in fibroblasts (Figure 3).

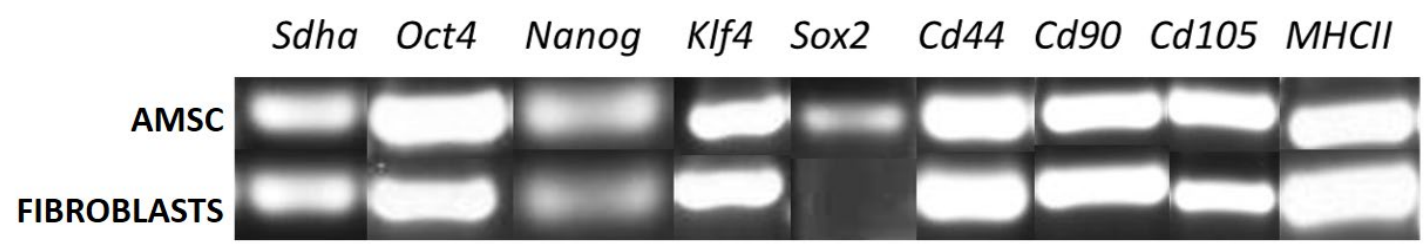

Figure 3. Agarose gel electrophoresis of the comparative expression of selected transcripts from AMSC and dermal fibroblasts from Puma concolor. Pluripotency genes: Oct4, Nanog, KIf4 and Sox2. Surface markers: CD44, CD90 and Major histocompatibility complex MHCIl. Sdha was employed as a housekeeping. Molecular weight ladder is not shown, the length of the amplicons for each transcript is indicated in Table 2.

Regarding protein analysis, OCT4 was detected in AMSCs both in cytoplasmic and nuclear location, while SOX2 was mildly expressed only at cytoplasmic level (Figure 4). 


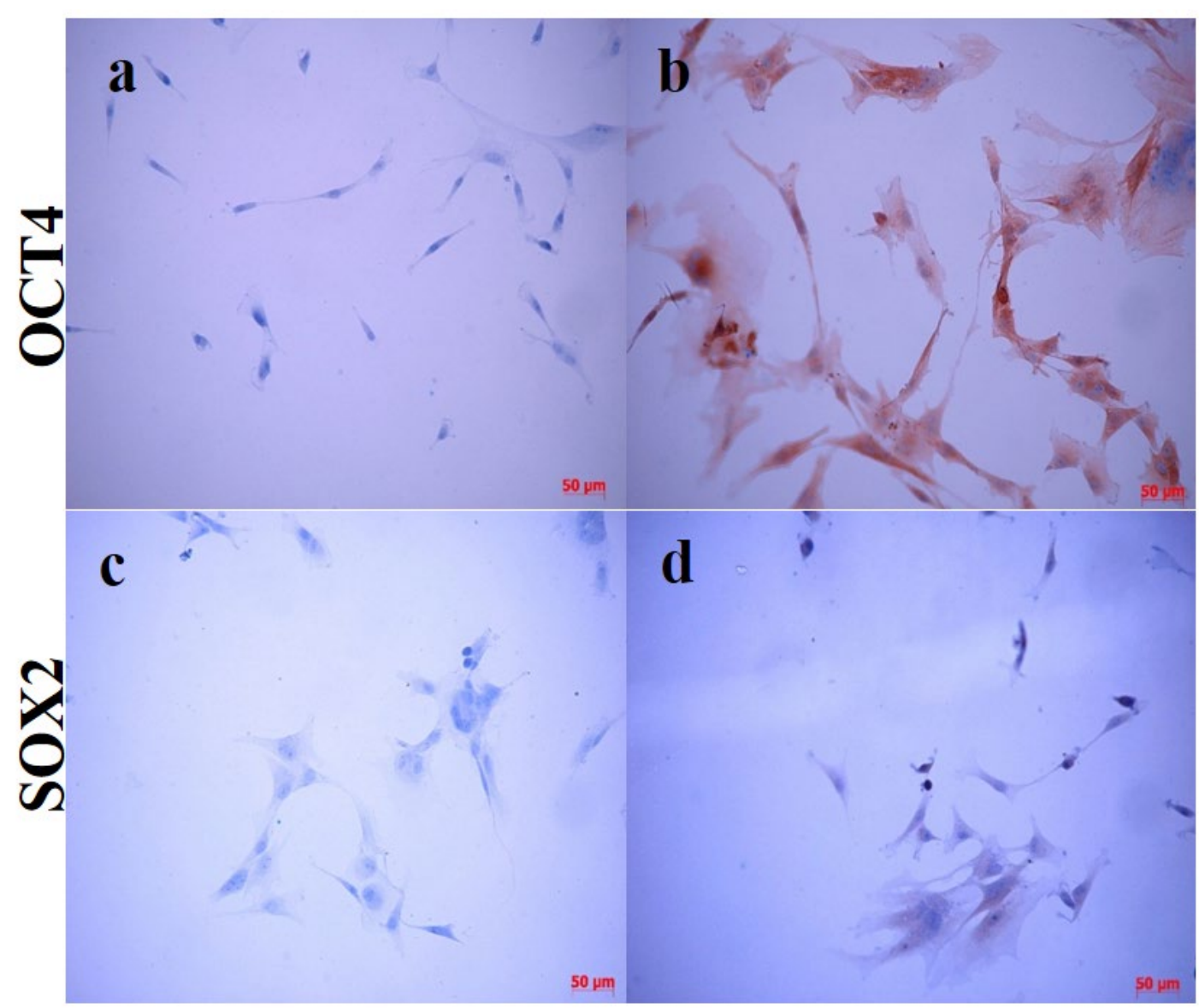

Figure 4. Detection of OCT4 and SOX2 by immunocytochemistry in AMSC from Puma concolor. (a and c) negative controls of expression for OCT4 and SOX2 respectively; the cells were fixed, primary antibody was omitted and the cells were incubated with the secondary anti-rabbit HRP sheep conjugated antibody and revealed with DAB; (b) Strong detection of OCT4 in cytoplasm and nuclei and (d) SOX2 immunodetection in the cytoplasm of some cells. Antibodies, catalogue numbers and specificity are described in materials and methods.

\section{Discussion}

Here we report for the first time partial characterization of AMSCs from cougar. The isolation of AMSCs from subcutaneous and abdominal tissue of domestic and wild cats (Felis nigripes and Leopardus guigna) was previously reported (Kono et al., 2014; Gómez et al., 2015; Echeverry et al., 2019). Here we isolated and characterized MSCs isolated from adipose tissue of Puma concolor. Cells showed similar morphology and growth kinetics to MSCs isolated from other felines like domestic cats and to fibroblasts. (Gómez et al., 2015; Clark et al., 2017; Lee et al., 2018; Echeverry et al., 2019). Noticeably, upon reaching confluence, starting at passages 4 and 5, growth was inhibited by contact and the cells detached from the plaque.

Our findings regarding expression of pluripotent and surface marker genes of cougar AMSCs are consistent with previous reports (Gómez et al., 2015; Lee et al., 2018; Echeverry et al., 2019). Others reported the expression of Oct4, Nanog, and KIf4 in fibroblast cells in humans (Page et al., 2009; Ambady et al., 2010; Rodríguez-Álvarez et al., 2013), and bovine species (Rodríguez-Álvarez et al., 2013). Basal levels of Nanog mRNA expression have been previously reported in fibroblasts of domestic cat (Gómez et al., 2015; Echeverry et al., 2019). Therefore our findings concerning these markers are in line with common literature for AMSCs.

Interestingly Sox2 mRNA expression were not reported earlier in AMSCs from wild cats. Conversely domestic cat, AMSC expressed Sox2 in early passages (P1-P3) but expression decreased after continuous culture (>P5) (Lee et al., 2018). In the present study Sox2 and 
pluripotent genes were evaluated at second passage only, therefor for these conditions, this agrees with the report of Lee et al., 2018, we did not attempt to identify Sox2 in later passages.

In human and bovine fibroblasts, OCT4 protein expression was reported (Rodríguez-Álvarez et al., 2013). Here we detected OCT4 and SOX2 proteins in the cultured AMSC. OCT4 was localized both in cytoplasm and nucleus of the AMSCs, while SOX2 was found only in the cytoplasm. Previous studies had reported OCT4 protein in the cytoplasm of fibroblasts cells, one explanation for this finding is the presence of OCT4 pseudogenes in bovine cells (Yadav et al., 2005). In human Oct4 encodes two different splice variants, described initially as Oct4A and Oct4B, where Oct4B is localized mainly in the cytoplasm of somatic cells (Lee et al., 2006). It has been reported in mouse embryonic stem cells that SOX2 can shift its localization pattern in early development from a cytoplasmic to a more nuclear distribution to contribute to pluripotency (Thevenet et al., 2004). Finding SOX2 at the cytoplasmic level may suggest response to differentiation signals or regulation of SOX2 via ubiquitination and proteasomal degradation (Baltus et al., 2009). For this reason, the finding of SOX2 in cougar AMSC cannot necessarily be attributed to multipotency features in these cells until further analysis is performed.

We found expression of KIf4 in fibroblasts and AMSC, this is coincident with Gómez et al., 2015, who found this gene expressed in fibroblasts and AMSC from cats. Probably the expression of $K I f 4$ is not pivotal to differentiate AMSC from fibroblasts in the feline species.

Further, we found mRNA expression of $\mathrm{MHCll}$ in both AMSC and fibroblasts contradictorily to results reported by other authors (Clark et al., 2017). However, it was not possible to confirm the expression of this marker at the protein level. Lack of expression of MHCII in AMSCs may ensure a beneficial effect in allogeneic cell therapies due to their low immunogenicity (Rutigliano et al., 2013). Others surface markers as MHCI and CD45 at mRNA and protein level needs to be evaluated.

Not shown here, we attempted to detect, $\mathrm{CD}$ proteins $\mathrm{CD} 44, \mathrm{CD} 90, \mathrm{MHCl}$ and $\mathrm{MHCll}$, by cell cytometer using antibodies raised against human said antigens, but they were not reliably detected. One possible explanation is the lack or low specificity of the used antibodies to feline antigenic epitopes (data no show). Specific species antibodies are required to perform more complete characterization of wild cat AMSC.

Cougar AMSCs showed multilineage differentiation potential towards adipogenic, osteogenic and chondrogenic lineage. The same was previously reported for domestic and wild cats (Kono et al., 2014; Gómez et al., 2015; Sato et al., 2016; Echeverry et al., 2019), but this is the first report of such differentiation for puma cells.

\section{Conclusion}

This study describes for the first time characterization of some biological attributes of presumed cougar ASMCS including growth kinetics and morphology, expression of pluri- and multipotent markers and tri-lineage mesodermal differentiation potential. Our results indicate that adipose tissue of Puma concolor contains AMSCs, which can be isolated, expanded and differentiated and thus might be of value for regenerative therapies in this species.

\section{Acknowledgements}

This research was funded partially by grants CONICYT, N 63140147 to D.E; Fondecyt Regular 1150757 to F.O.C. The authors thank the staff of the Wildlife Rehabilitation Center and the Veterinary Hospital at Universidad de Concepción, Chile.

\section{References}

Ambady S, Malcuit C, Kashpur O, Kole D, Holmes WF, Hedblom E, Page RL, Dominko T. Expression of NANOG and NANOGP8 in a variety of undifferentiated and differentiated human cells. Int J Dev Biol. 2010;54(11-12):1743-54. http://dx.doi.org/10.1387/ijdb.103192sa. PMid:21136380. 
Baltus GA, Kowalski MP, Zhai H, Tutter AV, Quinn D, Wall D, Kadam S. Acetylation of Sox2 induces its nuclear export in embryonic stem cells. Stem Cells. 2009;27(9):2175-84. http://dx.doi.org/10.1002/stem.168. PMid:19591226.

Cabezas J, Lara E, Pacha P, Rojas D, Veraguas D, Saravia F, Rodríguez-Alvarez L, Castro FO. The endometrium of cycling cows contains populations of putative mesenchymal progenitor cells. Reprod Domest Anim. 2014;49(4):550-9. http://dx.doi.org/10.1111/rda.12309. PMid:24754629.

Castro FO, Torres A, Cabezas J, Rodriguez-Alvarez L. Combined use of platelet rich plasma and vitamin C positively affects differentiation in vitro to mesodermal lineage of adult adipose equine mesenchymal stem cells. Res Vet Sci. 2014;96(1):95-101. http://dx.doi.org/10.1016/j.rvsc.2013.12.005. PMid:24377415.

Clark KC, Fierro FA, Ko EM, Walker NJ, Arzi B, Tepper CG, Dahlenburg H, Cicchetto A, Kol A, Marsh L, Murphy WJ, Fazel N, Borjesson DL. Human and feline adipose-derived mesenchymal stem cells have comparable phenotype, immunomodulatory functions, and transcriptome. Stem Cell Res Ther. 2017;8(1):69. http://dx.doi.org/10.1186/s13287-017-0528-z. PMid:28320483.

Echeverry DM, Rojas DM, Aguilera CJ, Veraguas DM, Cabezas JG, Rodríguez-Álvarez LL, Castro FO. Differentiation and multipotential characteristics of mesenchymal stem cells derived from adipose tissue of an endangered wild cat (leopardus guigna). Austral J Vet Sci. 2019;51(1):17-26. http://dx.doi.org/10.4067/S0719-81322019000100104.

Gómez MC, Qin Q, Biancardi MN, Galiguis J, Dumas C, MacLean RA, Wang G, Pope CE. Characterization and multilineage differentiation of domestic and black-footed cat mesenchymal stromal/stem cells from abdominal and subcutaneous adipose tissue. Cell Reprogram. 2015;17(5):376-92. http://dx.doi.org/10.1089/cell.2015.0040. PMid:26317245.

Holsback L, Cardoso MJL, Fagnani R, Patelli THC. Natural infection by endoparasites among free-living wild animals. Rev Bras Parasitol Vet. 2013;22(2):302-6. http://dx.doi.org/10.1590/S198429612013005000018 . PMid:23778826.

Kono S, Kazama T, Kano K, Harada K, Uechi M, Matsumoto T. Phenotypic and functional properties of feline dedifferentiated fat cells and adipose-derived stem cells. Vet J. 2014;199(1):88-96. http://dx.doi.org/10.1016/j.tvjl.2013.10.033. PMid:24300011.

Lee BY, Li Q, Song WJ, Chae HK, Kweon K, Ahn JO, Youn HY. Altered properties of feline adipose-derived mesenchymal stem cells during continuous in vitro cultivation. J Vet Med Sci. 2018;80(6):930-8. http://dx.doi.org/10.1292/jvms.17-0563. PMid:29669964.

Lee J, Kim HK, Rho JY, Han YM, Kim J. The human OCT-4 isoforms differ in their ability to confer selfrenewal. J Biol Chem. 2006;281(44):33554-65. http://dx.doi.org/10.1074/jbc.M603937200. PMid:16951404.

Miller RE, Lamberski N, Calle P, editors. Miller-Fowler's Zoo and Wild Animal Medicine Current Therapy. Vol. 9. USA: Elsevier Health Sciences; 2018. E-Book.

Page RL, Ambady S, Holmes WF, Vilner L, Kole D, Kashpur O, Huntress V, Vojtic I, Whitton H, Dominko T. Induction of stem cell gene expression in adult human fibroblasts without transgenes. Cloning Stem Cells. 2009;11(3):417-26 http://dx.doi.org/10.1089/clo.2009.0015.

Rodríguez-alvarez L, Manriquez J, Velasquez A, Castro FO. Constitutive expression of the embryonic stem cell marker OCT4 in bovine somatic donor cells influences blastocysts rate and quality after nucleus transfer. In Vitro Cell Dev Biol Animl. 2013; 49:657-67. http://dx.doi.org/10.1007/s11626-013-9650-0.

Rutigliano L, Corradetti B, Valentini L, Bizzaro D, Meucci A, Cremonesi F, Lange-Consiglio A. Molecular characterization and in vitro differentiation of feline progenitor-like amniotic epithelial cells. Stem Cell Res Ther. 2013;4(5):133. http://dx.doi.org/10.1186/scrt344. PMid:24405576.

Sato K, Yamawaki-Ogata A, Kanemoto I, Usui A, Narita Y. Isolation and characterization of peripheral blood-derived feline mesenchymal stem cells. Vet J. 2016;216:183-8. http://dx.doi.org/10.1016/j.tvjl.2016.08.009. PMid:27687950.

Thevenet L, Méjean C, Moniot B, Bonneaud N, Galéotti N, Aldrian-Herrada G, Poulat F, Berta P, Benkirane M, Boizet-Bonhoure B. Regulation of human SRY subcellular distribution by its acetylation/deacetylation. EMBO J. 2004;23(16):3336-45. http://dx.doi.org/10.1038/sj.emboj.7600352. PMid:15297880.

Uphoff CC, Drexler HG. Comparative PCR analysis for detection of mycoplasma infections in continuous cell lines. In Vitro Cell Dev Biol Animl. 2002; 38(2):79-85. http://dx.doi.org/10.1290/10712690(2002)038<0079:CPAFDO>2.0.CO;2 
Uphoff CC, Drexler HG. Detecting Mycoplasma Contamination in Cell Cultures by Polymerase Chain Reaction. In: Langdon SP, editor. Cancer Cell Culture. Methods in Molecular Medicine. USA: Humana Press; 2004:319-326. https://doi.org/10.1385/1-59259-406-9:319

Yadav PS, Kues WA, Herrmann D, Carnwath JW, Niemann H. Bovine ICM derived cells express the Oct4 ortholog. Mol Reprod Dev. 2005;72(2):182-90. http://dx.doi.org/10.1002/mrd.20343. PMid:15973686.

\section{Author's contributions}

DME: Conceptualization, Methodology, Formal analysis, Writing - original draft; PAA: Methodology; DMR: Methodology; CJA: Methodology; LRA: Data curation, Funding acquisition, Writing - review \& editing; FOC: Conceptualization, Data curation, Formal analysis, Writing - review \& editing, Funding acquisition. 
ERRATA

\title{
Errata
}

In the article "Characterization of mesenchymal stem cells derived from adipose tissue of a cougar (Puma concolor)", published in journal Animal Reproduction, 2020, volume 17, issue 2, the DOI number was published incorrectly.

\author{
Where it reads: \\ https://doi.org/10.21451/1984-3143-AR2019-0109 \\ It should be read: \\ https://doi.org/10.1590/1984-3143-AR2019-0109
}

